\title{
Unilateral phrenic nerve lesion in Lyme neuroborreliosis
}

Marija Djukic ${ }^{1,4^{*}}$, Jörg Larsen ${ }^{2}$, Paul Lingor ${ }^{3}$ and Roland Nau ${ }^{1,4}$

\begin{abstract}
Background: Among a variety of more common differential diagnoses, the aetiology of acute respiratory failure includes Lyme neuroborreliosis.

Case presentation: We report an 87-years old huntsman with unilateral phrenic nerve palsy as a consequence of Lyme neuroborreliosis.

Conclusion: Although Lyme neuroborreliosis is a rare cause of diaphragmatic weakness, it should be considered in the differential workup because of its potentially treatable nature.
\end{abstract}

Keywords: Phrenic nerve palsy, Unilateral, Lyme neuroborreliosis, Dyspnoea, Diaphragm, Doxycycline, Ceftriaxone

\section{Background}

Lyme neuroborreliosis (LNB) is the neurological manifestation of the systemic infection caused by the spirochete Borrelia burgdorferi (BB) sensu lato. Clinical features of LNB are diverse and differ among European and American patients, most probably because of differences in the distribution of Borrelia species in Europe and North America [1,2]. The most common neurological manifestation of LNB in European adults is polyradiculoneuritis (Bannwarth's syndrome) [3], which typically occurs in patients older than 50 years, while in younger patients a meningitic syndrome of LNB is common [4]. Although several studies indicate that severe paralysis may occur in LNB [1], diaphragmatic weakness as a symptom of LNB is rare [2]. Here we report a case of LNB leading to a reduction of vital capacity and severe dyspnoea as a consequence of unilateral paralysis of the diaphragm.

\section{Case presentation}

An 87-years old huntsman presented with severe headache, shooting left-sided thoracic pain, fatigue and vertigo. Neurological examination revealed partial dysfunction of the right abducens nerve. During the course of the disease

\footnotetext{
*Correspondence: mdjukic@gwdg.de

'Department of Neuropathology, University Medical Centre Goettingen,

Robert-Koch-Str. 40, 37075 Goettingen, Germany

${ }^{4}$ Department of Geriatrics, Weende Teaching Hospitals, An der Lutter 24,

37075 Goettingen, Germany

Full list of author information is available at the end of the article
}

a right facial palsy, with dysarthria and dysphagia as a consequence of facial weakness developed. Although the patient reported multiple previous tick bites, he had never noticed an erythema migrans. Brain magnetic resonance imaging (MRI) without and with contrast medium was unremarkable. The cerebrospinal fluid (CSF) analysis revealed a lymphocytic pleocytosis (129 cells/ $\mu \mathrm{l})$, an elevated lactate level of $2,6 \mathrm{mmol} / \mathrm{l}$, a protein level of $1324 \mathrm{mg} / \mathrm{l}$ and an intrathecal Borrelia burgdorferi (BB)IgG antibodies synthesis ( $B B$-specific antibody index for IgG 5.0 and for IgM 0.8). BB-PCR of CSF was negative. The negative CSF PCR for $B B$-specific DNA does not exclude the diagnosis, as the sensitivity of PCR in LNB is very low [5].

These findings led to the diagnosis of acute LNB. The patient was treated with intravenous ceftriaxone at a dose of $2 \mathrm{~g} / \mathrm{d}$ for two weeks. His symptoms of headache, dysarthria and dysphagia improved, facial and abducens nerve palsies recovered slowly. Two days following his discharge from hospital, the patient developed dyspnoea and a mild cough. The clinical diagnosis upon out-patient review was pneumonia, and the patient was admitted again. Biplanar chest radiography showed a partial atelectasis of the left lower lobe, and screening fluoroscopy showed paralysis of the left hemidiaphragm (Figure 1A), but no air-space shadowing indicative of pneumonia. No leucocytosis or elevated C-reactive protein were found on laboratory analysis. Oral antibiotic treatment with doxycyclin $(200 \mathrm{mg} / \mathrm{d})$ was commenced and continued for 


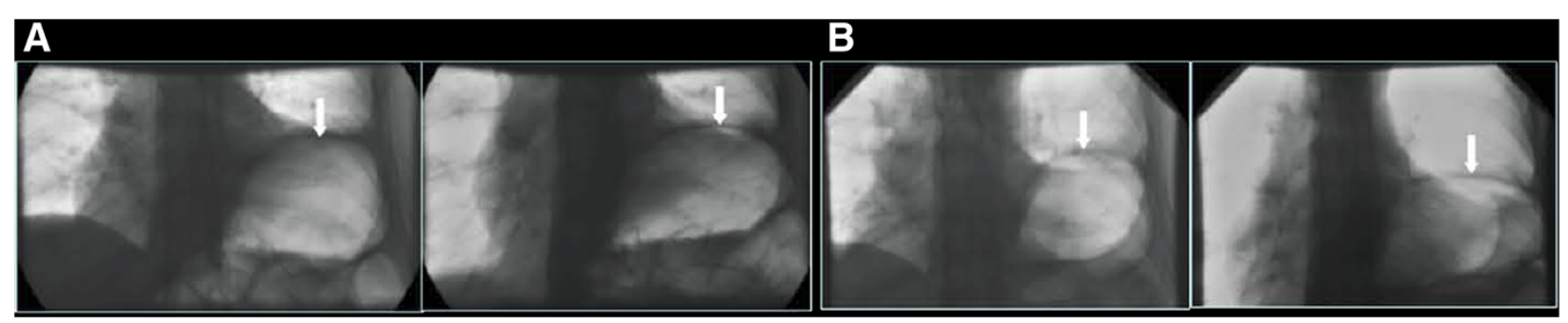

Figure 1 Frontal projection screening fluoroscopy images of the patient's diaphragms during spontaneous ventilation in Lyme neuroborreliosis. At the time when the patient's dyspnoea developed (Panel $\mathbf{A}$ ), there was no significant change in the position and shape of the left hemidiaphragm between expiration (left) and inspiration (right; arrows). Six months following treatment (Panel B), there was relative depression and, specifically, flattening of the left hemidiaphragm on inspiration (right as compared to left image; arrows). Note relative splinting of the left hemidiaphragm due to gaseous distension of the gastric fundus (all images).

14 days, since LNB was considered the probable cause of the diaphragmatic weakness. During the following two weeks dyspnoea did, however, not resolve. Pulmonary function tests revealed a vital capacity of 2.61 . To exclude a mass lesion of the lung, chest computerised tomography (CT) was done. It confirmed elevation of the left hemidiaphragm and partial atelectasis of the left lower lobe, associated with a small pleural effusion without detection of other lung lesions. Bronchoscopy was unremarkable, so that no other cause for the paralysis was found. Diaphragmatic paralysis in our patient became first evident after the presentation with typical clinical neurological features of acute LNB and CSF findings indicating a recent infection with $B B$.

Six months later, the patient had no dyspnoea at rest but continued to be short of breath on exertion. Repeat fluoroscopic examination showed partial recovery of the diaphragmatic weakness (Figure 1B). The abducens nerve palsy had recovered completely, but a mild facial palsy remained.

Lyme borreliosis may involve all parts of the nervous system [1] with as many as $15-20 \%$ of infected patients developing neurological symptoms [6]. These usually occur in the first three months following the infection. Diaphragmatic weakness has been associated with trauma, malignant compression or infiltration, metabolic, inflammatory and other disorders, but rarely with Lyme disease [7]. Early recognition and appropriate treatment of diaphragmatic paralysis caused by $B B$ is important in order to shorten the duration of severe respiratory symptoms [7].

Unilateral diaphragmatic paralysis is a respiratory disorder, and many neurological diseases, such as spinal cord injury, motor neuron disease, and carcinomatous infiltration of the phrenic nerve are included in its differential diagnosis [8]. The development of respiratory compromise due to peripheral nerve involvement in patients with LNB is rare. To our knowledge, only 8 such patients have been described in the literature [7,9-13]. The severity of the respiratory involvement varies from mild symptoms to the need for artificial ventilation for several months $[7,13]$. In the last published report, as many as three patients with diaphragmatic weakness caused by LNB presented over a one-year period. This suggests that the incidence of LNB as a cause of diaphragmatic weakness is underestimated [13].

Diaphragmatic weakness in LNB results from radiculopathy of the nerve roots $\mathrm{C} 3-\mathrm{C} 5$ or neuropathy of the phrenic nerve [13]. The pathogenesis of the nervous system involvement is uncertain: both direct infection with stimulation of Toll-like receptors [14] as well as immunological mechanisms with stimulation of $\mathrm{T}$ - and $\mathrm{B}$ cells [15] may play a role.

As in the present case, the clinical diagnosis of LNB is based on a combination of history, typical clinical symptoms, the detection of $B B$ antibodies in serum and CSF and calculation of the $B B$-specific antibody index [4]. $B B$ antibody tests in serum may be negative in early infection. Conversely, serum antibodies against $B B$ are detectable in up to $25 \%$ of healthy persons in Europe [16]. In some patients, antibodies against $B B$ may be detectable in CSF slightly earlier than in serum [4]. Both $B B$ specific antibodies in serum and $B B$-specific intrathecal antibody synthesis can persist for years after eradication of the infection [17]. In recent years, the B lymphocyte chemoattractant chemokine CXCL13 has been identified as a potentially important biomarker for the diagnosis of acute LNB $[18,19]$. CXCL13, however, seems to be the major determinant for B cell recruitment to the CNS compartments in different neuroinflammatory diseases and not just in LNB [20]. CXCL13 levels in the CSF rather reflect a strong humoral immune response in the CNS compartments than being specific for a particular disease entity [20].

The marked inflammatory response in CSF (lymphopleocytosis and production of $B B$-specific antibodies and the absence of other causes) indicate an acute Lyme neuroborreliosis as the reason for respiratory failure in the present case. Irrespective of appropriate antibiotic therapy, diaphragmatic dysfunction in our patient persisted for a 
long period. Treatment with adequate antimicrobial regimens is usually effective in LNB [21] but some symptoms may persist longer despite antibiotic treatment, and the recovery can be incomplete [22-24].

\section{Conclusion}

LNB should be considered in the differential diagnosis of acute respiratory failure due to diaphragmatic paralysis since it requires adequate antibiotic treatment. It is important in clinical practice to consider Lyme neuroborreliosis also in patients presenting with respiratory failure as an isolated syndrome.

\section{Consent}

Written informed consent was obtained from the patient for publication of this Case report and any accompanying images. A copy of the written consent is available for review by the Series Editor of this journal.

\section{Competing interests}

There are non-financial competing interests.

\section{Authors' contribution}

MD and RN made substantial contributions to conception and design, analysis and interpretation of data. $J \mathrm{~L}$ and $\mathrm{PL}$ were involved in drafting the manuscript, revising it critically for the intellectual content. All authors read and approved the final manuscript.

\section{Acknowledgement}

This study was supported and funded by the Robert Bosch Foundation (to M. Djukic) and by the Else Kröner-Fresenius-Stiftung (to R.Nau).

\section{Author details}

'Department of Neuropathology, University Medical Centre Goettingen, Robert-Koch-Str. 40, 37075 Goettingen, Germany. ${ }^{2}$ Department of Clinical Radiology, Weende Teaching Hospitals, An der Lutter 24, 37075 Goettingen, Germany. ${ }^{3}$ Department of Neurology, University Medical Centre Goettingen, Robert-Koch-Str. 40, 37075 Goettingen, Germany. ${ }^{4}$ Department of Geriatrics, Weende Teaching Hospitals, An der Lutter 24, 37075 Goettingen, Germany.

Received: 27 June 2012 Accepted: 10 January 2013

Published: 18 January 2013

\section{References}

1. Hansen $\mathrm{K}$, Lebech AM: The clinical and epidemiological profile of Lyme neuroborreliosis in Denmark 1985-1990. A prospective study of 187 patients with Borrelia burgdorferi specific intrathecal antibody production. Brain 1992, 115:399-423.

2. Ljostad U, Skarpaas T, Mygland A: Clinical usefulness of intrathecal antibody testing in acute Lyme neuroborreliosis. Eur J Neurol 2007, 14:873-876

3. Bannwarth A: Chronische lymphozytäre Meningitis, entzündliche Polyneuritis and Rheumatismus. Arch Psychiatr Nervenkr 1941, 113:284-376.

4. Djukic M, Schmidt-Samoa C, Spreer A, Lange P, Neubieser K, Eiffert H, Nau R, Schmidt H: Cerebrospinal fluid findings in adults with acute Lyme neuroborreliosis. J Neurol 2012, 259:630-636.

5. Lebech AM, Hansen K, Brandrup F, Clemmensen O, Halkier-Sørensen L: Diagnostic value of PCR for detection of Borrelia burgdorferi DNA in clinical specimens from patients with erythema migrans and Lyme neuroborreliosis. Mol Diagn 2000, 5:139-150.

6. Steere AC: Lyme disease. NEJM 1989, 321:586-596.

7. Abbott RA, Hammans S, Margarson M, Aji BM: Diaphragmatic paralysis and respiratory failure as a complication of Lyme disease. I Neurol Neurosurg Psychiatry 2005, 76:1306-1307.
8. Kumar N, Folger WN, Bolton CF: Dyspnea as the predominant manifestation of bilateral phrenic neuropathy. Mayo Clin Proc 2004, 79:1563-1565

9. Sigler S, Kershaw P, Scheuch R, Sklarek H, Halperin J: Respiratory failure due to Lyme meningoradiculitis. Am J Med 1997, 103:544-547.

10. Faul JL, Ruoss S, Doyle RL, Kao PN: Diaphragmatic paralysis due to Lyme disease. Eur Respir J 1999, 13:700-702.

11. Winterholler $\mathrm{M}$, Erbguth $\mathrm{FJ}$ : Tick bite induced respiratory failure. Diaphragm palsy in Lyme disease. Intensive Care Med 2001, 27:1095.

12. Ishaq $S$, Quinet $R$, Saba J: Phrenic nerve paralysis secondary to Lyme neuroborreliosis. Neurology 2002, 59:1810-1811.

13. van Egmond ME, Luijckx GJ, Kramer H, Benne CA, Slebos DJ, van Assen S: Diaphragmatic weakness caused by neuroborreliosis. Clin Neurol Neurosurg 2011, 113:153-155.

14. Tauber SC, Ribes S, Ebert S, Heinz T, Fingerle V, Bunkowski S, Kugelstadt D, Spreer A, Jahn O, Eiffert H, Nau R: Long-term intrathecal infusion of outer surface protein C from Borrelia burgdorferi causes axonal damage. I Neuropathol Exp Neurol 2011, 70:748-757.

15. Lünemann JD, Gelderblom H, Sospedra M, Quandt JA, Pinilla C, Marques A, Martin R: Cerebrospinal fluid-infiltrating CD4+ T cells recognize Borrelia burgdorferi lysine-enriched protein domains and central nervous system autoantigens in early lyme encephalitis. Infect Immun 2007, 75:243-251.

16. Kaiser R, Kern A, Kampa D, Neumann-Haefelin D: Prevalence of antibodies to Borrelia burgdorferi and tick-borne encephalitis virus in an endemic region in southern Germany. Zentralbl Bakteriol 1997, 286:534-541.

17. Hammers-Berggren S, Hansen K, Lebech AM, Karlsson M: Borrelia burgdorferi-specific intrathecal antibody production in neuroborreliosis: a follow-up study. Neurology 1993, 43:169-175.

18. Schmidt C, Plate A, Angele B, Pfister HW, Wick M, Koedel U, Rupprecht TA: A prospective study on the role of CXCL13 in Lyme neuroborreliosis. Neurology 2011, 76:1051-1058.

19. Rupprecht TA, Pfister HW, Angele B, Kastenhauer S, Wilske B, Koedel U: The chemokine $\mathrm{CXCL} 13$ (BLC): a putative diagnostic marker for neuroborreliosis. Neurology 2005, 65:448-450.

20. Kowarik MC, Cepok S, Sellner J, Grummel V, Weber MS, Korn T, Berthele A, Hemmer B: CXCL13 is the major determinant for B cell recruitment to the CSF during neuroinflammation. J Neuroinflammation 2012, 9:93.

21. Halperin JJ: Neurologic manifestations of lyme disease. Curr Infect Dis Rep 2011, 13:360-366.

22. Mygland A, Skarpaas T, Ljøstad U: Chronic polyneuropathy and Lyme disease. Eur J Neurol 2006, 13:1213-1215.

23. Ackermann R, Rehse-Kupper B, Gollmer E, Schmidt R: Chronic neurologic manifestations of erythema migrans borreliosis. Ann N Y Acad Sci 1988, 539:16-23.

24. Kaiser R: Clinical courses of acute and chronic neuroborreliosis following treatment with ceftriaxone. Nervenarzt 2004, 75:553-557.

doi:10.1186/1471-2466-13-4

Cite this article as: Djukic et al:: Unilateral phrenic nerve lesion in Lyme neuroborreliosis. BMC Pulmonary Medicine 2013 13:4.

\section{Submit your next manuscript to BioMed Central and take full advantage of:}

- Convenient online submission

- Thorough peer review

- No space constraints or color figure charges

- Immediate publication on acceptance

- Inclusion in PubMed, CAS, Scopus and Google Scholar

- Research which is freely available for redistribution 